\title{
Eurozone's Future: The Political Economy of Structural Convergence
}

\author{
Antonin Rusek \\ Susquehanna University, Selinsgrove, USA
}

Doi: 10.19044/elp.v4no1a1 URL:http://dx.doi.org/10.19044/elp.v4no1a1

\begin{abstract}
The progress of globalization confronts the EU with the new challenges. To answer these, the restoration of growth is the imperative. The competitiveness and hopefully the real convergence must be restored. Capital flows are the sine qua non of this development. The key in this endeavor is the capital markets union, i.e. the set of the structural reforms which will facilitate the increased activities of the venture capital - the main tool to create the new economy of innovation and creativity. But to be successful the capital markets union has to be complemented structural convergence of labor markets, business creation environment and taxation. New approaches like special "economic innovation and growth" zones may be necessary. To fully implement the necessary structural reforms and the convergence processes, the cooperation of the private and public sectors on both the EU and national levels is necessary.
\end{abstract}

Keywords: Challenges of globalization, structural reforms, structural convergence.

\section{Introduction}

This paper analyzes the issue of the structural convergence in the Eurozone: the concept, the role, history and the relationship between the perceived "need" for this type of a convergence and political and economic realities.

The nominal convergence is the key to the functioning of a monetary union. It determines the effectiveness of monetary policy, especially in the organization like EMU (Eurozone), where the monetary centralization operates in the environment of decentralized fiscal structures, limited fiscal transfers and a very limited labor mobility. The real convergence is crucial for the political and social stability, which in turn determines the degree of commitment to the preservation of the common endeavor - i.e. the EU itself. 
Finally, the structural convergence determines both the effectiveness of common policies and ultimately the form of the EU commonality itself.

The role of the structural convergence is not ignored by European authorities. Their answer appears to be twofold. On the one side steps are taken to increase the European integration by expanding the common economic institutions. The major steps here are the Banking Union (in the process of implementation) and the Capital Markets Union (in the beginning). On the other side is the idea of a structural convergence understood as a process of creating the similar (if not the same) legal and institutional environment in all areas of economic activity in all states sharing the common currency, provided that the autonomy of individual states and hence the existing principles underlying the European treaties are preserved.

The twin concepts of the structural reform and structural convergence are discussed in Part II. Part III then reviews the structural convergence processes (or the lack thereof) in the context of the EU (and the Eurozone) history. The controversies and sometimes conflicts stemming from the diversity of EU members and their political realities are discussed in Part IV. Part V then concludes.

\section{Structural Reforms and Structural Convergence: Basic Ideas}

Any discussion of the issue is conditioned on the definition of the subject. What is the "structural convergence" or for that matter the "structural divergence"? In this analysis we accept the interpretation of the term "structural" as describing the set of preferences, political, economic, social and legal institutions and the associated policies and decision making processes. (I.e. we exclude the interpretation of "structural" as referring to the composition of economic activities and industries as in Wacziarg, 2001.) Given this interpretation (which we believe corresponds to the meaning of "structural" in Buti and Turrini (2015) and Juncker at el. (2015)), two types of "structural convergence" actions are possible within the boundaries of the EU and the Eurozone.

One, which could be called the "absolute" structural convergence is the transfer of institutional arrangements, policy formulations and decisionmaking procedures to the EU (or the Eurozone) levels. Participating member states experience the $100 \%$ loss of an autonomy in such cases. The history of the European integration can be interpreted as this type of the structural convergence. It includes a wide variety of actions, from the "European Treaties" (the Lisbon Treaty of 2009 is the last in the long line of those), binding decisions of the European summits (some may require ratifications by the participating countries) to the EU commission directives and judgements of the European Court of Justice. 
Institutional, policy and decision making structures apply uniformly across the participating countries. It can be argued that this process of the absolute structural convergence in Europe was rather successful in general terms, even if the lack of a real convergence might suggest otherwise. (It is far beyond the subject of this paper to provide a detailed discussion of the history of European integration. Moreover, the real economic convergence often fails even in the unified national states - Italy is the best known example - where the structural convergence is absolute by definition.)

In the context of the EU and the Eurozone the latest examples of absolute structural convergence are the ongoing projects of the Banking Union and the Capital Markets Union. High hopes are associated with these projects as far as the real convergence is concerned - but results are still in the future.

Second type of a structural convergence addresses the situation when the institutional or policy arrangements in different countries are getting closer together (becoming the "more similar"). But the jurisdiction remains on the national level, with no (or a very limited) common EU action.

The discussions (and sometimes actions) in this area are related mostly to labor markets, business creations and operations environments, and legal structures and procedures. Taxation, health care and education are also involved. The basic idea is the identification and the subsequent emulation of the "best practice" - with the hope that this will contribute to the real convergence and the EU and the Eurozone's political and social stability.

Structural reforms and structural convergence are closely related but not necessarily the same activities. Obviously, the processes of a structural convergence imply structural changes in one or more countries, whether they are domestically initiated or introduced on the EU level. However, not all structural reforms policy steps qualify as a "structural convergence". More will be said on this topic in part IV. Here it suffices to say that in the EU context, even some of the most successful structural reforms from the domestic political and social standpoint (like often discussed "Hartz IV" reforms in Germany) may actually increase the "structural divergence" on the EU level. Obviously, this phenomenon calls for more attention on both the EU and individual states levels.

\section{Structural Reforms and Structural Convergence: 60 Years of European Integration}

EU traces its origin to the Rome treaty of 1957. Officially the Treaty establishing the European Economic Community is the international agreement that led to the creation of the European Economic Community (EEC). Signed by Belgium, France, Italy, Luxembourg, the Netherlands and West Germany, it came into force on 1 January 1958. 
The EEC treaty committed the participants to the progressive reduction of customs duties and the establishment of a customs union. It gradually created a single market for goods, labour, services, and capital across the EEC's member states. It also implied the creation of common transport and agriculture policies and the European social fund and established the European Commission.

Moreover, in the process of the EEC treaty implementation, the institutional framework of the European Community (Common Market) was established and the principles of the "division of labor" between the Community center (located in Brussels, Belgium) and the national governments of member states was introduced.

The processes establishing the European Economic Community culminated in the Single European Act (SEA), signed in Luxembourg and The Hague in 1986 (effective July $1^{\text {st }}, 1987$ ).

SEA defined the European Council, (the periodical meetings of Heads of State and Government) as the place where major political negotiations take place among the member States and strategic decisions are adopted. The competences of the European Parliament were reinforced.

Most importantly, the measures were adopted to finalize the common market by December $31^{\text {st }}$, 1992.This was defined as an area without obstacles to free movement of goods, people, services and capitals. This goal was summed up in 282 detailed measures and the true common market became a reality.

Additionally The Single Market Act included diverse initiatives to promote an integration in the spheres of social rights (health and the workers' security), research and technology, and environment. To achieve the objective of a greater economic and social cohesion among the diverse countries and regions of the Community, reform and financial support to the denominated Structural Funds, European Agricultural Guidance and Guarantee Fund (EAGGF), European Regional Development Fund (ERDF), European Social Fund (ESF) was settled.

The period from 1958 to 1993 (ie. from the Rome to Maastricht treaties) can be characterized as the period of both significant structural reforms and a structural convergence. However, some caution is needed here. Most of the "structural convergence" was achieved via EU directives, which imposed the identical legal cum regulatory structure on all member countries. But even the directives became operational only after they became a part of the legal system of individual countries via a legislative action in those countries. Most of the structural reforms required to comply with the emerging "European" economic reality remained in jurisdiction of individual states - which ex post tended toward a "structural convergence", but not always and in all cases. 
But it is very important to note the areas which remained outside any structural convergence consideration. First and foremost, it was macroeconomic policy - both monetary and fiscal. Obviously, the attempts to commit to the exchange rate stability (from the mid 70s) had implications for monetary policy, but actual executions were left to the discretion of the national central banks. On the fiscal side the "tax harmonization" was extensively discussed, but with no practical implications.

Other policy left essentially at discretions of national governments were labor markets and social/cum welfare policies and banking and financial markets regulations - with the small exemptions in the form of European social fund and structural funds.

The collapse of the Russian Soviet Empire and the liberation of the captive East European nations changed the basic environment for the European economic integration project. German unification (October $2^{\text {nd }}$, 1990) changed the internal equilibrium of European communities. Simultaneously, the emergence of newly free nation states between the EEC and Russia threaten the area with political, economic and perhaps military instability.

EEC's answer to the new reality was twofold. On the one side the more decision and policy making powers were shifted toward the transnational center, away from individual states. This increase in a supranational character included some policy issues over and above purely economic ones. On the other side, the European integration was to expand, including (gradually) the European states formerly outside the EEC (Austria, Sweden and Finland) and, in longer horizon, the remaining European states in the Mediterranean (Malta and Greek Cyprus) and the newly liberated countries in the East (Czech Republic, Slovakia, Slovenia, Poland, Latvia, Lithuania, Estonia and Hungary in 2005, Rumania and Bulgaria in 2007 and Croatia in 2013). Conceptually, those changes were introduced by the Treaty of Maastricht (which established the European Union (EU) as we know it today and became effective November $\left.1^{\text {st }}, 1993\right)$. Following treaties of Amsterdam (effective May $\left.1^{\text {st }}, 1999\right)$, Nice (effective February $\left.1^{\text {st }}, 2003\right)$ and Lisbon (effective December $1^{\text {st }}$, 2009) specified and detailed the processes of the EU structural transformation.

Maastricht treaty is considered to be a significant step not only toward EMU (economic and monetary union) but toward an European political union as well. As a such it constituted a milestone in the process of the structural convergence, both on the transnational (i.e. the union) level and national levels. Establishment of the common European currency (the Euro) is the most visible demonstration of a structural change - it concentrates the monetary policy in the one place - the ECB. 
But equally important from the standpoint of the structural convergence are Maastricht provisions in the areas of the effectiveness of the institutions; development of the Community social dimension and the establishment of a common foreign and security policy. ( For details, see Treaty of Maastricht on European Union (2010).)

To facilitate the EU and its decision making structures and processes during a significant expansion (from 12 countries which signed the Maastricht treaty to 15 in 1996, 25 in 2004, 27 in 2007 and 28 in 2013), the Maastricht treaty was modified and expanded by the Treaty of Amsterdam in 1997 and the treaty of Nice in 2001. (It may be informative to mention here that the Schengen treaty establishing free travel within the EU, initially signed in 1985, became the integral part of the EU law via the Amsterdam treaty.)

It was expected that the process of structural reforms and structural convergence, through which the intergovernmental organization of European Economic Communities (EEC) will be succeeded by the transnational European Union, will be crowned by the European Constitution, signed in Rome in October 2004. However, the ratification process failed (the EU Constitution was rejected by popular referenda in France in May 2005 and in Netherlands in June 2005) and the EU Constitution never became operational.

Instead, the basic features (structural reforms and convergence) of now defunct EU constitution were incorporated in the new Lisbon Treaty, which became effective in October 2009 (see Treaty of Lisbon (2015)). However, even if Lisbon treaty increased the role and decision making powers of the transeuropean institutions at the expense of nation-states (a very important structural reform), it still defines the European Union as the intergovernmental arrangement. (It should be noted in this context that the Lisbon treaty is the first to determine the possibility of a country to leave the EU - the article 50 of the treaty.)

The onset of the world financial crisis in 2008 revealed some weaknesses in the EU structural architecture, especially an incompatibility between the single currency monetary arrangement (by definition centralized on the EU - i.e. the ECB - level), and the fiscal policy and behavior which remained in the competences of the constituent nation states.

EU response to the financial crisis was multifaceted. The Treaty on Stability, Cooperation and Governance (TSCG) imposed the stronger rules of fiscal discipline on the participating states and introduced the new concepts of fiscal policies coordination and supervision. (For more details, see Main Elements of Fiscal Compact (2012)). TSCG clearly represents a significant elements of structural reforms and convergence on the EU level, even if 
significant elements of fiscal policies (composition of public expenditures, tax systems) remain in remits of individual nation states.

To further stabilize the fiscal position of individual states, European Stability Mechanism (ESM) was created as the emergency safety fund of the 500 billions of Euro. Finally, the European Central Bank (ECB) adopted the program of Outright Monetary Transactions (OMT), the purchase of sovereign debt on secondary markets, provided that the original issuer of such bonds complies with TSCG and/or specific stabilization programs.

TSCG, ESM and OMT together restored the fiscal and financial stabilities in the EU - with a special emphasis on the Eurozone. Nominal convergence - the key precondition for the effectiveness of ECB policies was restored. However, the strict application of stabilization policies, necessary as it might be, exacerbated the real divergencies among the EU's and especially the Eurozone's member countries.

Combined with the protracted differential impact of the rise of emerging markets on different EU member states (positive for North, but basically negative for South - see Chen et al, 2012), real divergencies triggered a creeping political instability, clearly visible recently. This trend was only exacerbated by social political trends, among which the immigration, both intra and extra EU plays a significant role. Finally, it should be pointed out in this context that some very successful structural reforms in some member states (like Hartz IV reforms in Germany in 20032004) probably contributed to both structural and real divergencies in the EU and (especially) in the Eurozone.

\section{What Next?}

Each organization (and EU is undoubtedly one) needs a modicum of structural and behavioral stability. This includes social, political and economic institutions, legal system and, indeed, most of both external and internal environments. Such a stability makes the results of decisions of all agents predictable (albeit only in a statistical sense) - hence it provides for a dynamically functioning society in all its aspects.

Simultaneously, an organization must be flexible enough to cope with challenges stemming from changing both external and internal environments. For political-economic organizations (independent states and state-like entities) the most important internal challenges stem from economictechnological dynamics (which includes the impact of innovation processes) and demographics, which includes changing age cohorts, immigration dynamics and the impact of education in general. External challenges are then direct - i.e. the threat that the external agents or environment will, in a one form or another, extinguish the organization - or indirect, when changes 
in external environment make a functioning of an organization increasingly difficult.

Structural changes and convergence processes described in the previous part created a functioning organization of sovereign states, with rather significant elements of transnational structures. However, in many important structural aspects this organization remains incomplete. This incompleteness then affects both the current EU stability and ability to respond the challenges, both internal and external.

Some of the perceived shortages are being addressed, albeit rather slowly. "European Banking Union" transfers responsibility for "systemically important" banks from the national to the EU levels - a step which may be called $100 \%$ structural convergence.

(Responsibility for small local banks remains on the national levels).

Banking Union composes of three pillars. Single Supervisory Mechanism (SSM), which grants the European Central Bank (ECB) a supervisory role to monitor the implementation of the single rulebook and the financial stability participating banks.

The Single Resolution Mechanism (SRM - not completed yet) is a proposed pillar that would centrally implement the common rulebook's Bank Recovery and Resolution Directive in participating Member States, and would establish a Single Resolution Fund (SRF) to finance their restructuring. Agreements defining the EU Banking Union became operational in November 2016. The Banking Union itself will become fully effective in 2023 when the Single resolution fund is scheduled to be completely financed.

The key to the process of restoring the economic dynamism and (desirably) the real convergence is the establishment of the Capital Markets Union. The concept and intention was introduced in February 2015. This concept is the key for the establishment of the vigorous venture capital sector, which in turn facilitates the economy of creativity and innovation the key to economic growth in the todays globalized economy. However in the last two years the work on the Capital Markets Union effectively stalled, even if discussions continue.

It may be argued that TSCG, Banking Union and Capital Market Union, supported by ESM and ECB policies, form the structural framework on which the further structural integration policies can and should be build. It is an appealing proposition, but this structural-institutional framework is far from complete and some of its features remain unclear.

Even then, for the framework to do its job, both EU and the individual member countries (preferably in the cooperative manner) must provide corresponding changes - i.e. the structural reforms - especially in the areas of labor markets, business creation and operation and taxation. 
The key is to introduce reforms which would facilitate the rise in productivity necessary to increase both economic growth and competitiveness - the latter on the global scale. The problem, as the literature on varieties of capitalism indicates (for introduction, see Hall and Soskice, 2001), is that the effective reforms may differ from country to country, depending on the individual countries histories, traditions, path of developments, social-political realities etc. (In this context it may be instructive that the very successful German reforms of labor markets and social welfare policies, known collectively as Hartz IV, did not find any followers.). Structural reforms in the areas indicated in the previous paragraph may be a sine qua non of the EU survival, but the concept of the structural convergence in this area remains controversial. Obviously, a lot of research and certainly some creative thinking is required here.

Further obstacles to the structural convergence in the EU come from the inconsistency between the existing EU's principles (and resulting regulations and decisions of the ECJ (European Court of Justice)) and the economic realities stemming from the unequal economic levels among the member states.

This situation is illustrated by problems in labor markets and related social welfare, healthcare and pension areas. Single Market agreement and the concept of the "Four Freedoms" guarantee the citizens of every EU state the freedom of residency and employment anywhere on the EU territory. Whereas desirable on the ground of the more efficient allocation of limited existing resources (labor), combined with the existing differences in social welfare programs and provisions these policies result in the controversial phenomenon of the "welfare" or "benefit" tourism - the situation where residents of relatively "poorer" countries move to the more "affluent" ones in order to receive better welfare benefits, often without work. (Albeit controversial, polls indicate that the phenomenon of immigration associated with the welfare tourism was one of the major causes of the "leave" vote in the June 2016 British EU referendum.)

And, indeed, "welfare tourism" implies additional costs and complications in Healthcare provisions and pensions (down the line). Given the perceived negative impact on "genuine" residents of recipient countries, any structural convergence in this area is unlikely. Contemplated structural reforms - like the proposed 5 years working residency period before any legibility for welfare provisions in Germany - tend to increase structural divergences.

Additional difficulties for structural convergence are in the area of taxation. Whereas it is true that some countries (Ireland) use the tax system to attract businesses and hence to promote the economic growth, in general the issue is more complicated. In most of the countries the structure of the 
tax system is closely tied with the structure of public expenditures, especially in the areas of unemployment compensation, social expenditures, health care, education and pensions. Changing one without changing the other is extremely difficult. Hence any kind of a structural convergence here would imply social and political changes few countries are willing to contemplate, especially if such changes would appear to be initiated from the outside. (The 30 plus years history of the so called "tax harmonization" illustrates the point. Only agreement achieved here is the $15 \%$ minimum on the VAT with some well defined exemptions. Currently, the discussion concentrate on the "common corporate tax base" as a precondition for the desired common corporate tax structure. Certainly not inconsequential, but...)

The discussion above indicates that in the current socio-political environment, a significant progress in the EU structural convergence is unlikely. And, indeed, as the case of the UK referendum demonstrates, some "structural convergence" steps may be counterproductive. (Moreover, as Gros (2016) argues, the result of structural reforms remain unclear.)

However, some - admittedly partial - steps in structural convergence are desirable, in some cases even necessary for the restoration of growth.

For example, the impact of the Capital Markets Union would be enhanced if individual countries designate "economic growth and innovation areas" defined either territorially or perhaps as branches of economic activities. Within those areas, the structural reforms should be accelerated, with the aim to create a hospitable environment for the new businesses, preferably financed by the venture capital.

The special nature of these areas and their success can be enhanced by an adjusted tax and labor markets regime, limited to those areas, but otherwise similar between countries.

To address the corrosive nature of "welfare tourism" and simultaneously to preserve the essential freedoms of movement and work, the binding EU regulation imposing the minimum time of working residence for the eligibility for social payments should be adopted. In the meantime the affected individuals should be eligible for social payments from their country of birth. To facilitate labor markets flexibility, the short term eligibility for the unemployment compensation in the country of residence should be preserved.

Finally, to increase the EU cohesion, promote the labor mobility and the freedom of occupation and residence, the structural convergence cum reform of pension systems across the EU is desirable. The portability of pension income is the key issue here.

American type of a system, where an individual contributes a fixed percentage of his income to the public fund, independently on the employer and geographical location and employers are required to match these 
contributions is appealing, however... This system (Social Security) provides only $40-60 \%$ of an average retiree income. The rest comes from the private, albeit heavily regulated, pension funds.

System attraction is in its independence - both for contributions and payments - on the place and type of underlying economic activities. However, its integral counterpart - the private pension funds - are underdeveloped in the EU and, in fact, constrained by the rather underdeveloped (compared to USA) financial sector. Moreover, its functioning establishment would require an extensive transition period (decades). Finally, there is a question of the "transitional" financial costs.

More suitable for the European circumstances would be to determine the "minimum retirement income", applicable uniformly across the EU and financed from the tax revenues of individual countries. Retirement payments over and above this minimum would be provided by different jurisdictions according to individual's tax contributions in these jurisdictions. Indeed, the system would have to be unified across the EU - hence the element of a "structural convergence". Such a system (obviously, the details go beyond the scope of this analysis) would provide a pension portability and hence would contribute both to labor mobility and an increased productivity via improved resource allocation.

\section{Conclusion}

The discussion in this analysis indicates that the 60 years of the European integration history can be interpreted as the combined processes of structural reforms and the structural convergence. The effort was largely successful, resulting in the creation of an economic body of almost 450 million people (post Brexit). And, indeed, it is the biggest voluntary nonmilitary association of countries dedicated to freedom and liberty in the world history.

However, attempts to move beyond the economic aspects of the European integration are much less successful and often trigger resentment. And this reality includes not only immigration (both internal and external), but elements of fiscal policies - both taxation and expenditures - as well. Obviously, the wish is not strong enough to erase 1500 years of history and to form a single European identity. Such an identity should be built gradually, building on and incorporating existing diversities, not only economic, but cultural and historical as well.

Structural reforms - i.e. the structural convergence - are indeed useful and if designed thoughtfully they may be the key for overcoming the real divergence. However, the subject is far from simple and it would be naïve to expect the quick results. 


\section{References:}

Buti, Marco, Turrini, Alessandro ((2015). Three waves of convergence. Can Eurozone Countries start growing together again? VOX CEPR's Policy Portal, April 17th.

Chen, R., Milesi-Ferretti, G-M, and Tressel, T. (2012)." External imbalances in the Euro Area." IMF Working Paper, 12/236.

Gros, Daniel (2016). Structural Reforms as Panacea? The European Productivity and Growth Puzzle. Intereconomics vol. 51, no. 6, December Hall, Peter A., Soskice, David (2001). Varieties of Capitalism: The Institutional Foundations of Comparative Advantage. Oxford University Press, Oxford, UK.

Juncker, Jean-Claude, Tusk, Donald, Dijsseelbloem, Jeroen, Draghi, Mario (2015). Preparing for Next Steps on Better Economic Governance in the Euro Area. Informal European Council, Brusseless, Belgium, February 12th. Main Elements Of Fiscal Compact (2012). ECB Monthly Bulletin, March, p. 102

Treaty of Lisbon (2015) http://eur-lex.europa.eu/legalcontent/EN/TXT/?uri=uriserv\%3Aai0033

Treaty of Maastricht on European Union (2010) http://eurlex.europa.eu/legal-content/EN/TXT/?uri=URISERV\%3Axy0026

Wacziarg, Romain (2001). Structural Convergence. Mimeo. Stanford University, Stanford, USA, April. 